\title{
Adeno-Associated Virus Overexpression of Angiotensin-Converting Enzyme-2 Reverses Diabetic Retinopathy in Type 1 Diabetes in Mice

James M. Dominguez, II, ${ }^{* \dagger}$ Ping Hu, ${ }^{\dagger}$ Sergio Caballero, ${ }^{\dagger}$ Leni Moldovan, ${ }^{\dagger}$ Amrisha Verma, ${ }^{\ddagger}$ Gavin Y. Oudit, ${ }^{\S}$ Qiuhong Li, ${ }^{\ddagger}$ and Maria B. Grant

From the Department of Pharmacology and Therapeutics, ${ }^{*}$ and the Department of Ophthalmology and Powell Gene Therapy Center, ${ }^{\ddagger}$ University of Florida College of Medicine, University of Florida, Gainesville, Florida; the Department of Ophthalmology, ${ }^{\dagger}$ Indiana University School of Medicine, Indianapolis, Indiana; and the Department of Medicine ${ }^{\S}$ Mazankowski Alberta Heart Institute, University of Alberta, Edmonton, Canada

\author{
Accepted for publication \\ January 19, 2016. \\ Address correspondence to \\ Maria B. Grant, M.D., Eugene \\ and Marilyn Glick Eye \\ Institute, R3-C416, Indiana \\ University, Indianapolis, \\ IN 46202. E-mail: mabgrant@ \\ iupui.edu.
}

\begin{abstract}
Angiotensin-converting enzyme ( $\mathrm{ACE})-2$ is the primary enzyme of the vasoprotective axis of the renin angiotensin system that regulates the classic renin angiotensin system axis. We aimed to determine whether local retinal overexpression of adenoassociated virus (AAV)-ACE2 prevents or reverses diabetic retinopathy. Green fluorescent protein (GFP)-chimeric mice were generated to distinguish resident (retinal) from infiltrating bone marrow-derived inflammatory cells and were made diabetic using streptozotocin injections. Retinal digestion using trypsin was performed and acellular capillaries enumerated. Capillary occlusion by $\mathrm{GFP}^{+}$cells was used to measure leukostasis. Overexpression of ACE2 prevented (prevention cohort: untreated diabetic, $11.3 \pm 1.4 ;$ ACE2 diabetic, $6.4 \pm 0.9$ per $\mathrm{mm}^{2}$ ) and partially reversed (reversal cohort: untreated diabetic, $15.7 \pm 1.9$; ACE2 diabetic, $6.5 \pm 1.2$ per $\mathrm{mm}^{2}$ ) the diabetes-associated increase of acellular capillaries and the increase of infiltrating inflammatory cells into the retina $\left(\mathrm{F} 4 / 80^{+}\right)$(prevention cohort: untreated diabetic, $24.2 \pm 6.7$; ACE2 diabetic, $2.5 \pm 1.6$ per $\mathrm{mm}^{2}$; reversal cohort: untreated diabetic, $56.8 \pm 5.2$; ACE2 diabetic, $5.6 \pm 2.3$ per $\mathrm{mm}^{2}$ ). In both study cohorts, intracapillary bone marrow-derived cells, indicative of leukostasis, were only observed in diabetic animals receiving control AAV injections. These results indicate that diabetic retinopathy, and possibly other diabetic microvascular complications, can be prevented and reversed by locally restoring the balance between the classic and vasoprotective renin angiotensin system. (Am J Pathol 2016, 186: 1688-1700; http://dx.doi.org/10.1016/j.ajpath.2016.01.023)
\end{abstract}

Microvascular complications of diabetes constitute a number of painful and debilitating conditions. Previously, we found that the bone marrow is susceptible to diabetic neuropathy, 1,2 which leads to denervation of stromal cells and altered secretion of growth factors and cytokines that ultimately shifts hematopoiesis toward a disproportionate increase of proinflammatory monocytes. ${ }^{3,4}$ Consequently, monocytes are increased in the circulation and subsequently in tissues subject to diabetic complications, including retina, kidney, and brain. ${ }^{5}$ Diabetic retinopathy (DR), the most common diabetic microvascular complication and the leading cause of blindness in working adults, is characterized by inflammation, leukostasis, and microangiopathy. Current treatment options are symptomatic and suboptimal, and prevention strategies are limited to aggressive regulation of blood pressure, lipids, and glucose. ${ }^{6}$ However, studies suggest that manipulation of the systemic and local retinal renin angiotensin system (RAS) may offer new and powerful therapeutic options.

The levels of almost all proinflammatory, classic RAS components [prorenin, renin, angiotensinogen, angiotensinconverting enzyme (ACE)-1, angiotensin II (Ang II), and the Ang II type 1 receptor (AGTR1)] are significantly

Supported by NIH grants EY-07739, EY-12601, DK-090730-02, EY-018358, EY-021626, HL-110170 (all to M.B.G.), and EY-021752 (Q.L.). Core facilities were supported by NIH National Eye Institute grant P30 EY-02172 and Research to Prevent Blindness.

Disclosures: None declared. 
elevated in ocular tissues of diabetic patients ${ }^{7,8}$ and animals. ${ }^{9,10}$ Accordingly, systemically administered ACE1 inhibitors and AGTR1 antagonists attenuate retinal microvascular disease in diabetic rodents by decreasing vascular hyperpermeability, acellular capillaries, and the expression of angiogenic factors, such as vascular endothelial growth factor. $^{9,11}$ Despite the clear success of systemic RAS blockade in diabetic rodents, systemic suppression in humans has led to only marginal improvement. AGTR1 blockade decreased the incidence of DR in individuals with type 1 diabetes and improved mild and moderate DR in those with type 2 diabetes. However, AGTR1 blockade did not influence DR progression or DR at the more advanced stages once ischemic changes were present. ${ }^{12,13}$ The most widely proposed explanation for this shortcoming is that the blood-retinal barrier limits access of therapeutic concentrations of systemically administered pharmaceuticals, such that suppression of the classic RAS in ocular tissues fails to occur. ${ }^{10}$ From these data, the notion has emerged that restoring the balance between the classic RAS and its endogenous counterbalance, the vasoprotective RAS, represents a viable strategy for controlling DR in humans. The crucial enzyme in this axis is ACE2, which converts the vasoconstrictive and proinflammatory peptide, Ang II, into the vasodilatory and anti-inflammatory peptide, angiotensin(1-7) [Ang(1-7)], which mediates its effects primarily through the receptor Mas. ${ }^{14}$ Importantly, ACE1 inhibitors do not block the effects of ACE2. ${ }^{15}$

Thus, restoring the local retinal RAS balance, by bolstering the vasoprotective RAS, may diminish oxidative stress and chemokine production, decreasing inflammatory cell infiltration and preventing retinal vasodegeneration, the key histologic characteristic of DR. In this study, we asked whether local retinal overexpression of ACE2 could prevent or reverse the histologic features of DR in a mouse model of type 1 diabetes and whether a decrease in resident and bone marrow-derived inflammatory cells in the retina would occur.

\section{Materials and Methods}

\section{Experimental Approach}

The experimental paradigm is shown in Figure 1A for the prevention cohort and in Figure 1B for the reversal cohort. Briefly, the prevention cohort consisted of C57BL/6 mice that underwent bone marrow transplantation with hematopoietic progenitor cells from $G_{F P}{ }^{+}$mice. These $G F P^{+}$-chimeric mice received an intravitreal injection with adenoassociated virus (AAV)-ACE2 or AAV-reverse-GFP (control vector) and were subsequently made diabetic with streptozotocin (Figure 1A). This approach allowed us to test the hypothesis that retinal overexpression of ACE2 improves the diabetic phenotype of the retina, characterized by increased acellular capillaries and increased inflammatory cell expression. The reversal cohort tested the ability of retinal overexpression of ACE2 to reverse preexisting disease by administering
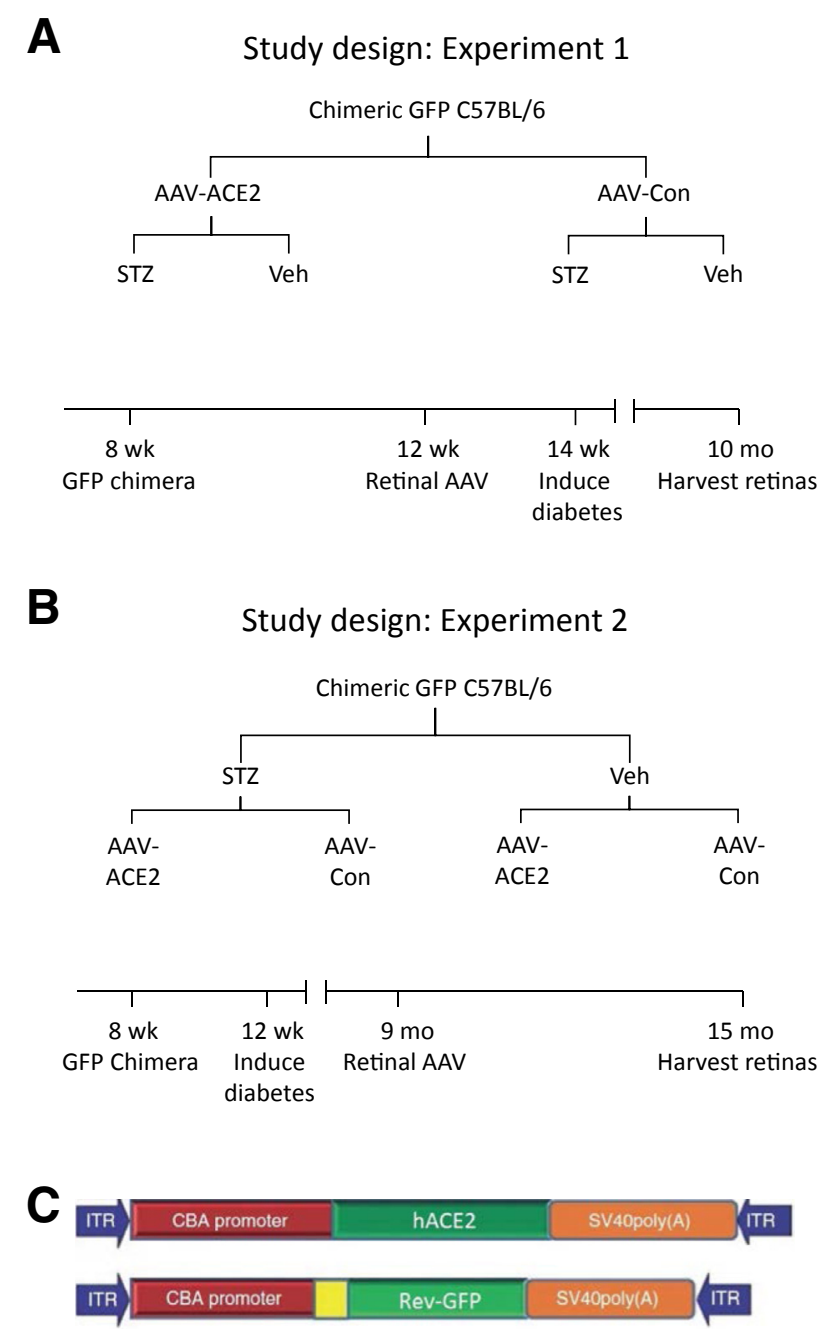

Figure 1 Experimental approach. A: Prevention cohort. B: Reversal cohort. C: Maps of the adenoassociated virus (AAV) vectors expressing the human ACE2 gene (hACE2) and the control (Con) vector expressing a reverse sequence for green fluorescent protein (GFP). ACE2, angiotensin-converting enzyme; CBA, chicken $\beta$-actin promoter; ITR, inverted terminal repeat; STZ, streptozotocin; Veh, vehicle. Adapted from Verma et al. ${ }^{10}$

streptozotocin 6 months before AAV injections (Figure 1B). Both studies used the same end points. The AAV constructs are shown in Figure 1C.

\section{Generation of GFP-Chimeric Mice}

We used two timeline sequences that enabled us to evaluate a prevention role (Figure 1A) and a reversal role (Figure 1B) for ACE2 overexpression. To determine whether retinal overexpression of ACE2 prevents the inflammatory bone marrow cell influx into the diabetic retina, C57BL/6-GFPchimeric mice were generated. Male C57BL/6 mice $(n=7$ per group), which were obtained commercially from The Jackson Laboratory (Bar Harbor, ME), were housed five per cage with unrestricted access to food and water with a 12:12 light:dark cycle. All procedures that involved mice were performed in accordance with the guidelines of the 
University of Florida Institutional Animal Care and Use Committee. GFP-chimeric mice were generated as previously described. ${ }^{16}$ Briefly, bone marrow was harvested from the femurs of $\mathrm{GFP}^{+}$transgenic (homozygous) mice. From the total bone marrow cells, the c-Kit ${ }^{+} \mathrm{Sca}-1^{+}$hematopoietic stem cells were purified by FACS using anti-GFP, antic-Kit, and anti-Sca-1 antibodies (BD Biosciences, San Jose, CA). Cells $(>5000)$ and were then injected into lethally irradiated adult C57BL/6 mice via retro-orbital sinus.

Streptozotocin-induced diabetes was induced by i.p. injection of streptozotocin $(50 \mathrm{mg} / \mathrm{kg}$ in $100 \mathrm{mmol} / \mathrm{L}$ sodium citrate, adjusted to $\mathrm{pH} 4.5$ ) for 5 consecutive days. Control mice were injected with sodium citrate (vehicle) alone. Diabetes was verified 2 weeks later by measuring blood glucose (defined as $>250 \mathrm{mg} / \mathrm{dL}$ ) using a glucometer (Glucometer Elite XL; Bayer Corp, Elkhart, IN) according to the manufacturer's instructions. Glycated hemoglobin was measured at the end of the study, and animals were considered diabetic if the glycated hemoglobin level was $>7.5 \%$.

\section{AAV Construct}

Maps of the AAV vectors used in this study are shown in Figure 1C. A secreted form of human ACE2 lacking the membrane domain, which has been previously characterized, ${ }^{17}$ was cloned into an AAV vector under the control of the chicken $\beta$-actin promoter and packaged into serotype 2 viral particles, as previously described. ${ }^{10}$ Serotype 2 typically infects ganglion cells in the ganglion cell layer and horizontal and amacrine cells in the inner nuclear layer. ${ }^{10}$ Previously, we found that this secreted, truncated ACE2 had approximately fourfold higher activity in media from transfected cells and approximately eightfold higher activity in serum collected from systemically injected neonatal rats when compared with the membrane-bound enzyme. ${ }^{17}$ This viral vector, delivered by intravitreal injection, resulted in a greater than twofold increase of ACE2 activity with a approximately $50 \%$ decrease of Ang II and a 2.3-fold increase of Ang(1-7) levels. ${ }^{10}$ The control vector contained a $G F P$ coding region in reverse sequence.

\section{ACE2 Activity Assay}

HEK293 cells were infected with ACE2-AAV2 triple mutant Y-F (reference K2742) at 5000 multiplicity of infection for 72 hours. Cells were washed in phosphatebuffered saline and harvested in ACE2 activity assay buffer (buffer has $1 \mathrm{mmol} / \mathrm{L}$ Tris- $\mathrm{HCl}, \mathrm{pH} 7.5,5 \mathrm{mmol} / \mathrm{L} \mathrm{NaCl}$, and $1 \mathrm{mmol} / \mathrm{L} \mathrm{ZnCl}_{2}$ ). Cells were sonicated for 20 seconds on ice and centrifuged at $6010 \times g$ for 20 minutes. The supernatant was subjected to protein estimation and used for ACE2 activity assay. The ACE2 activity assay was performed using $50 \mu \mathrm{g}$ of protein in black 96-well opaque plates with $50 \mu \mathrm{mol} / \mathrm{L}$ ACE2-specific fluorogenic peptide substrate VI (R\&D Systems, Minneapolis, MN) in a final volume of $100 \mu \mathrm{L}$ per well reaction mixture. The enzymatic activity was recorded in a SpectraMax M3 fluorescence microplate reader (Molecular Devices, LLC, Sunnyvale, CA) for 1 hour with 90 -second intervals at excitation 340 $\mathrm{nm}$ and emission $400 \mathrm{~nm}$.

\section{Intravitreal AAV Injections}

Eyes were dilated by topical administration of $1 \%$ atropine sulfate ophthalmic solution (Bausch \& Lomb, Tampa, FL) and $2.5 \%$ phenylephrine hydrochloride ophthalmic solution (Akorn, Vernon Hills, IL). Animals were then anesthetized by $72 \mathrm{mg} / \mathrm{kg}$ of i.p. ketamine and $4 \mathrm{mg} / \mathrm{kg}$ of xylazine injection. Intravitreal injection was made through sclera/ choroid into the vitreous cavity using a 33-gauge beveled sharp needle (Hamilton Company, Reno, NV). One microliter of AAV (approximately $10^{9} \mathrm{vg}$ ) was injected for each mouse eye. In the prevention cohort (Figure 1A), to ensure sufficient therapeutic expression of ACE2 before the onset of diabetes, AAV was injected intravitreally 2 weeks before induction of diabetes.

\section{ACE2 Activity Assay in Mouse Retina Injected with ACE2-AAV2 Viral Vector}

To confirm viral expression of ACE2, $1 \mu \mathrm{L}$ of viral vector (or phosphate-buffered saline as control) was injected into the vitreous of C57BL/6 mice. Mice were euthanized 3 weeks after injection, and retinal protein was extracted for ACE2 activity assay as described above.

\section{Trypsin Digest Preparation of Retinal Vasculature}

Retinal vasculature was prepared using the method described by Kuwabara and $\operatorname{Cogan}{ }^{18}$ with minor modifications. Retinas were scanned by an Aperio CS slide scanning system with Spectrum Plus information management system (Aperio Technologies, Inc., Vista, CA). Ten to 15 random, nonoverlapping fields of $100,000 \mu \mathrm{m}^{2}$ from each retina were imaged. Acellular capillaries $>50 \mu \mathrm{m}$ in length were counted from images for each retina and expressed as number of acellular vessels per square millimeter.

\section{Immunohistochemistry of Cryosections}

Sections were prepared as previously described. ${ }^{19}$ Primary antibodies were administered at 1:200 and secondary antibodies at 1:400. Antibodies included glial fibrillary acidic protein (GFAP) (ab53554; Abcam, Cambridge, England) plus secondary (ab150132; Abcam), F4/80 (ab6640; Abcam) plus secondary (Abcam; ab150160), and isolectin-B4 conjugated to DyLight 594 (DL-1207; Vector Laboratories, Burlingame, CA). Primary antibodies were allowed to incubate overnight at $4{ }^{\circ} \mathrm{C}$, whereas secondary antibodies incubated for 1 hour at room temperature. DAPI (Life Technologies, Carlsbad, CA) was applied at $300 \mathrm{nmol} / \mathrm{L}$ for 5 minutes at room temperature. Slides were then coverslipped with 

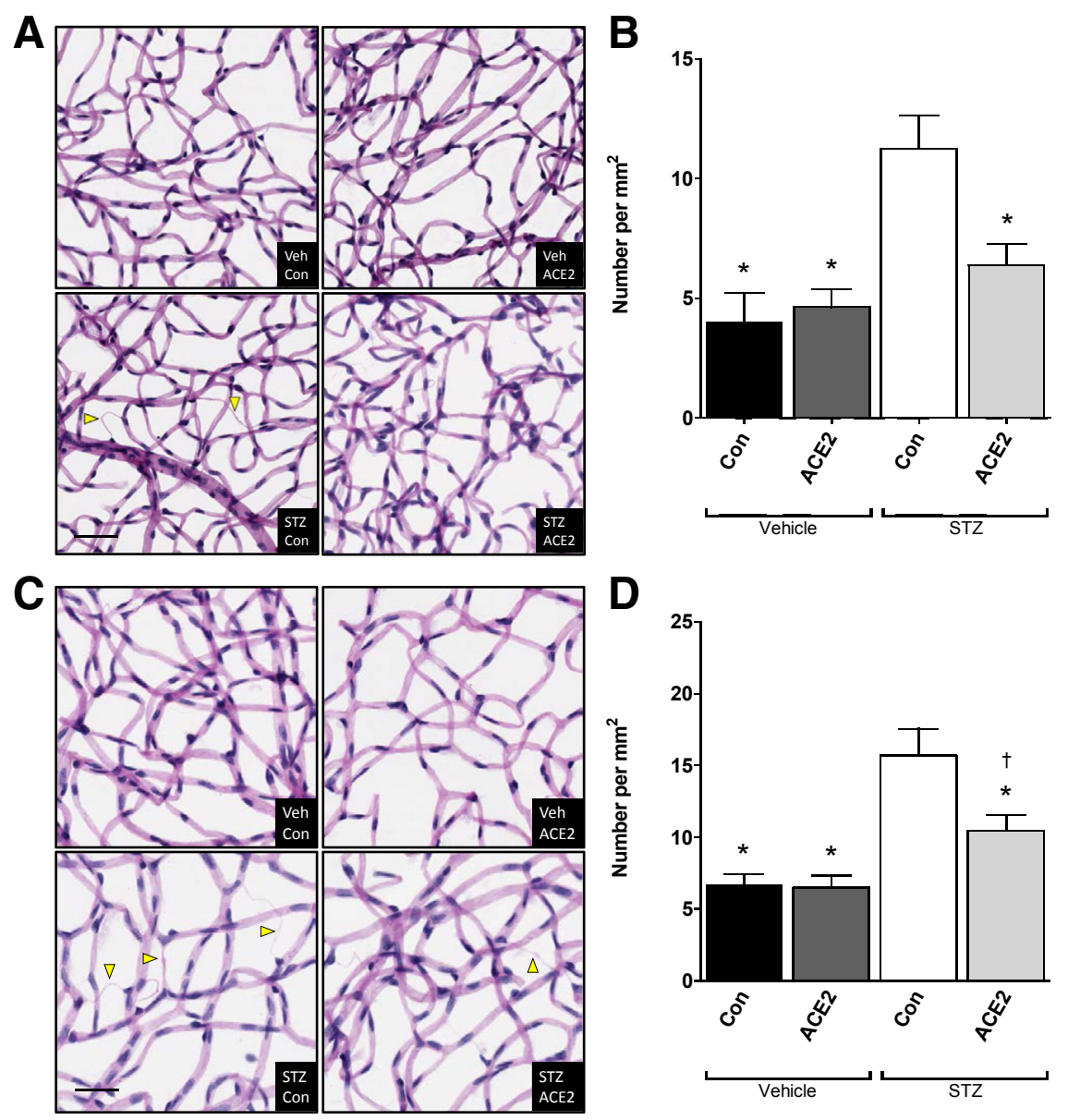

Figure 2 Angiotensin-converting enzyme (ACE)-2 overexpression decreases retinal acellular capillaries. A: Prevention cohort; representative images of retinal vasculature after trypsin digestion showing acellular capillaries (arrowheads) in green fluorescent protein (GFP)-chimeric, streptozotocin (STZ)-diabetic, and vehicle (Veh)control (Con) mouse retinas. B: Prevention cohort; quantification of retinal acellular capillaries. C: Reversal cohort; representative images of retinal vasculature after trypsin digestion showing acellular capillaries (arrowheads) in GFP-chimeric, STZ-diabetic, and Veh-Con mouse retinas. D: Reversal cohort; quantification of retinal acellular capillaries. Data are expressed as means \pm SEM. ${ }^{*} P<0.05$ versus STZ-Con; ${ }^{\dagger} P<0.05$ versus respective nondiabetic control. Scale bar $=50 \mu \mathrm{m}$. antifade medium (Vectashield; Vector Laboratories), and images were taken with a Hamamatsu digital camera (model C11440; Hamamatsu City, Shizuoka, Japan) through an inverted microscope (Zeiss Axio Imager.D2; Zeiss, Oberkochen, Germany) and photographed at $\times 20$ magnification. Positive fluorescence was quantified from three retinal sections per animal by manual counting of cells or by Aperio's Positive Pixel Count algorithm (Aperio Technologies, Inc., Vista, CA). Briefly, the ImageScope program (Aperio) uses the Positive Pixel Count algorithm to quantify positive staining based on a custom range of hues, saturation, and intensity for the fluorophore of interest. Negative controls for all targets were analyzed to ensure that the algorithm detected minimal false-positive results and autofluorescence.

\section{Localization of Bone Marrow-Derived Cells within Retinal Vasculature}

GSL I - isolectin B4, conjugated with Alexa-Fluor 594 (Vector Laboratories), was used in retinal cross sections to identify the vasculature. Leukostasis was assessed by enumeration of intraluminal leukocytes (bone marrow derived, $\mathrm{GFP}^{+}$) as nucleated cells devoid of dendritic processes. Three retinal cross sections from five animals per group were analyzed.

\section{Data Analysis}

All data were analyzed for outliers before treatment comparisons. Comparisons between the groups were assessed using a one-way analysis of variance followed by the Tukey post-hoc test. $P<0.05$ was considered significant.

\section{Results}

Overexpression of Vasoprotective RAS Reduces the Number of Acellular Capillaries

Streptozotocin-induced diabetes resulted in a significant decrease in body mass and a significant increase in glycated hemoglobin, as expected in streptozotocin mice in both cohorts (Supplemental Tables S1 and S2). The expression of the AAV-ACE2 virus was confirmed by increases in ACE2 activity in vitro after infection of HEK293 cells (Supplemental Figure S1A) and in vivo after injection of AAV-ACE 2 into the vitreous of wild-type mice (Supplemental Figure S1, B and C). Six months of hyperglycemia induced significant increases of retinal acellular capillaries in the untreated diabetic animals (streptozotocin-control group). Despite profound systemic hyperglycemia, the increase in acellular capillaries was prevented by intravitreal injection of AAV-ACE2 2 weeks 

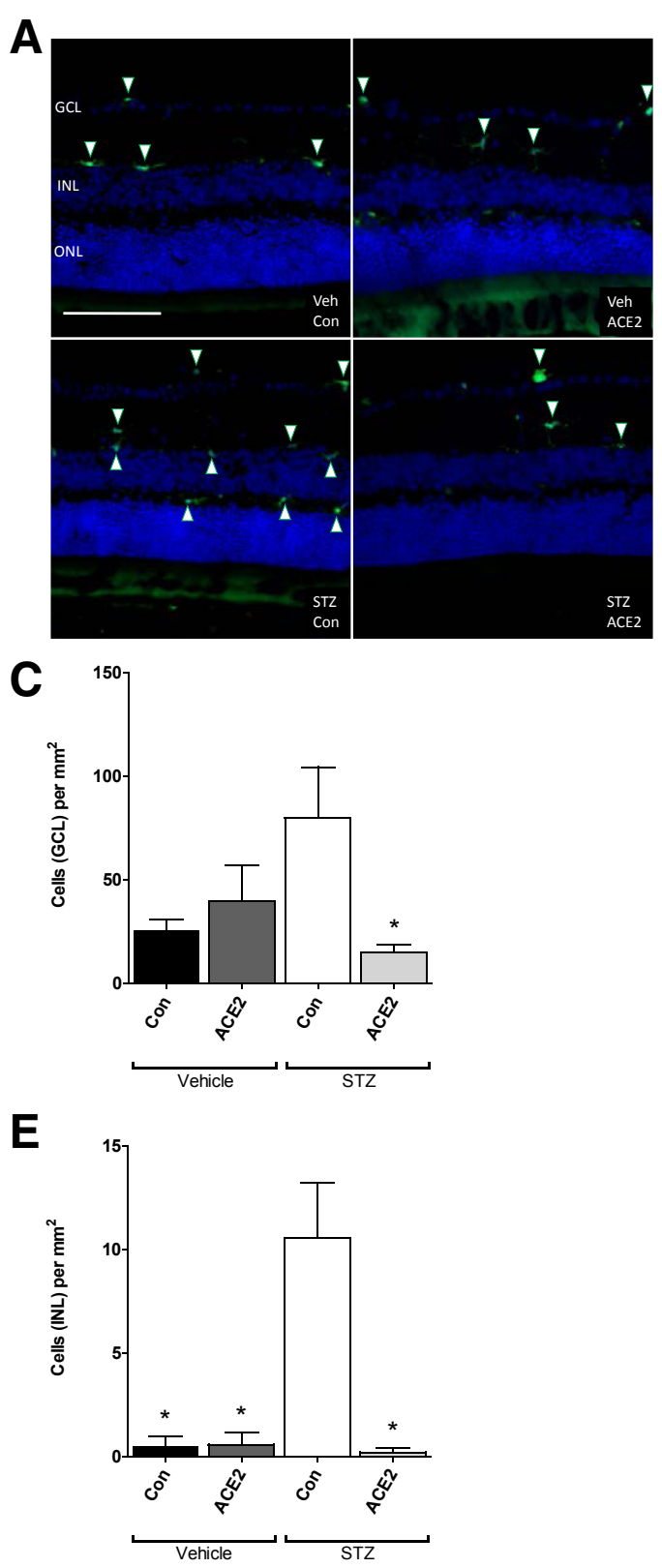

\section{B}
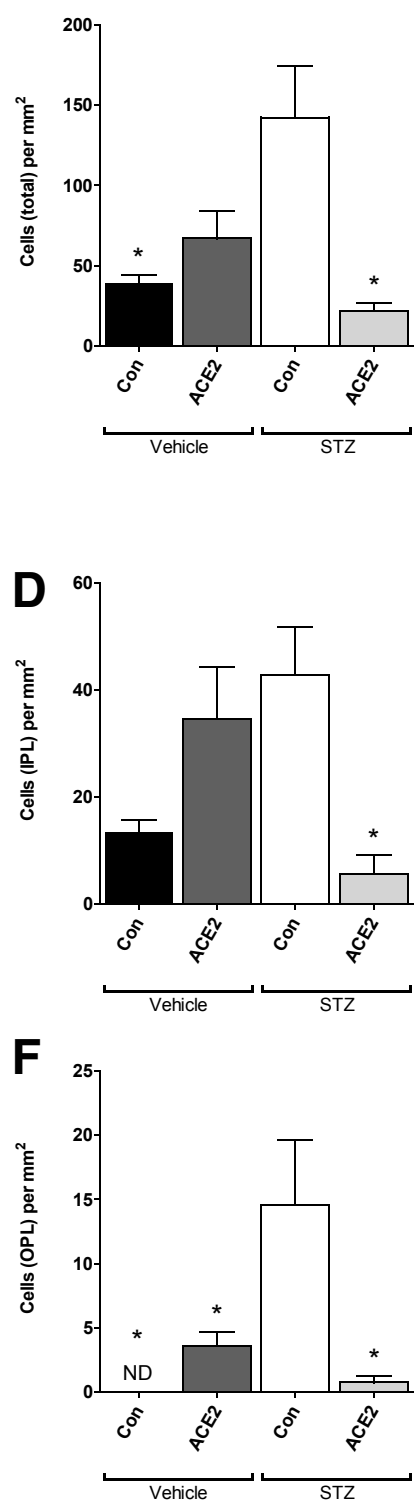

Figure 3 Angiotensin-converting enzyme (ACE)-2 overexpression reverses bone marrow cell infiltration. A: Reversal cohort; representative immunofluorescence images showing green fluorescent protein-positive $\left(\mathrm{GFP}^{+}\right)$cells (arrowheads) in GFP-chimeric, streptozotocin (STZ) - diabetic, and vehicle (Veh)-control (Con) mouse retinas. B-F: Reversal cohort; quantification of $\mathrm{GFP}^{+}$cells per square millimeter in the discrete retinal layers. B: Total cells in all layers. C: Ganglion cell layer. D: Inner plexiform layer. E: Inner nuclear layer. F: Outer plexiform layer. Data are expressed as means \pm SEM. ${ }^{*} P<0.05$ versus STZ-Con. Scale bar $=100 \mu \mathrm{m} . \mathrm{GCL}$, ganglion cell layer; INL, inner nuclear layer; IPL, inner plexiform layer; ND, no cells detected; ONL, outer nuclear layer. before streptozotocin administration (Figure 2, A and B). Similarly, 12 months of hyperglycemia resulted in increased acellular capillaries in the untreated diabetic group (streptozotocin-control group) and was partially reversed in the mice receiving AAV-ACE2 six months after streptozotocin administration (Figure 2, C and D).

\section{Bone Marrow Cells Preferentially Localize to Inner Retinal Layers}

Use of $\mathrm{GFP}^{+}$-chimeric mice allowed for the identification of cells originating from the bone marrow. In the mice that received intravitreal injections before the induction of diabetes (prevention cohort), the total number of retinal $\mathrm{GFP}^{+}$ cells was not different between the experimental groups
(Figure 3). Similarly, in this cohort, the number of $\mathrm{GFP}^{+}$ cells detected in individual retinal layers was not different between the experimental groups. In contrast, in mice receiving intravitreal injections 6 months after diabetes onset (reversal cohort), the total number of retinal $\mathrm{GFP}^{+}$ cells was highest in the untreated diabetic group (streptozotocin-control group) and was reduced with administration of AAV-ACE2 (Figure 3). In both the prevention cohort and the reversal cohort, infiltrating cells appeared predominantly along the anterior aspect of the ganglion cell layer and in the inner plexiform layer. In the prevention cohort, few $\mathrm{GFP}^{+}$ cells, irrespective of treatment group, were observed in the inner nuclear layer or outer plexiform layer.

Neither cohort had $\mathrm{GFP}^{+}$cells posterior to the outer plexiform layer. Another consistent observation in all groups, 


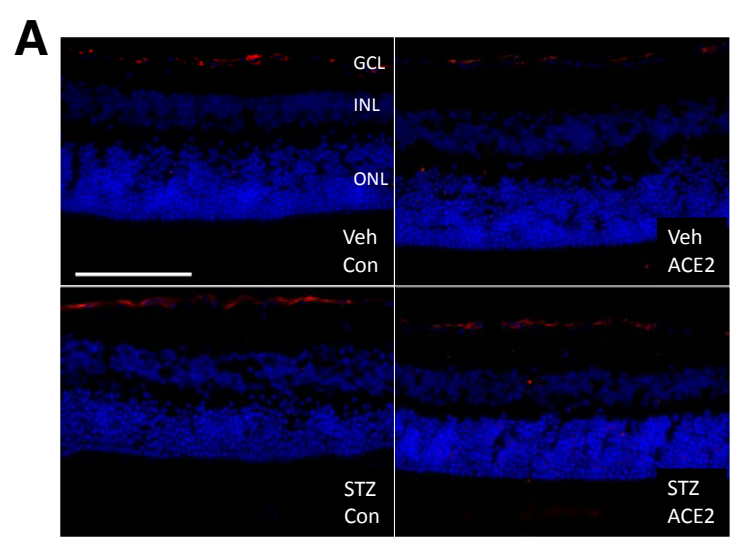

B

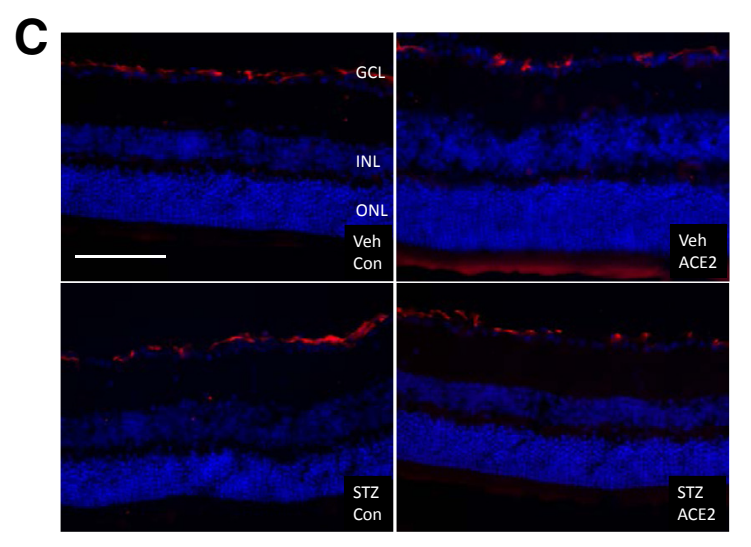

Figure 4 Angiotensin-converting enzyme (ACE)-2 overexpression prevents diabetes-induced increase of glial fibrillary acidic protein (GFAP) expression in the prevention study. A: Prevention cohort; representative immunofluorescence images showing GFAP-positive astrocytes (red). B: Prevention cohort; percent area of GFAP staining in green fluorescent protein (GFP)-chimeric, streptozotocin (STZ)-diabetic, and vehicle (Veh)-control (Con) mouse retinas. C: Reversal cohort; representative immunofluorescence images showing GFAP-positive astrocytes (red). D: Reversal cohort; percent area of GFAP staining in GFP-chimeric, STZ-diabetic, and Veh-Con mouse retinas. Data are expressed as percent area \pm SEM. ${ }^{*} P<0.05$ versus STZ-Con. Scale bar $=100 \mu \mathrm{m} . \mathrm{GCL}$, ganglion cell layer; $\mathrm{INL}$, inner nuclear layer; $\mathrm{ONL}$, outer nuclear layer.

in both the prevention and reversal cohorts, was the asymmetrical distribution of $\mathrm{GFP}^{+}$cells, from section to section, presumably reflecting localized regions of disease. ${ }^{20}$

\section{GFAP Immunohistochemistry in ACE2-0verexpressing Retinas}

GFAP is an intermediate filament and marker of astrocytes that is up-regulated during high glucose and neuronal damage. ${ }^{21,22}$ It is also interpreted as an indication of stress and damage in astrocytes. ${ }^{22}$ In the prevention cohort, diabetes was associated with elevated GFAP immunoreactivity compared with nondiabetic controls, and retinal overexpression of ACE2 in diabetic animals prevented this increase (Figure 4, A and B). In the reversal cohort, however, GFAP immunoreactivity in the diabetic animals was not different from the other groups (Figure 4, C and D). GFAP immunofluorescence was higher in the reversal cohort by approximately threefold compared with the prevention cohort, which is consistent with the observed age-associated increase in GFAP in normal, nondiabetic C57 mice. ${ }^{23}$

\section{F4/80 Immunohistochemistry in ACE2-0verexpressing Retinas}

F4/80 is a well-known and widely used marker of murine macrophage populations. ${ }^{24}$ In both the prevention and the reversal studies, $\mathrm{F} 4 / 80^{+}$cells were located within the ganglion cell layer of mice and were predominantly ameboid or elongated in appearance. Most $\mathrm{F} 4 / 80^{+}$cells were also $\mathrm{GFP}^{+}$and existed in clusters. This finding is not unexpected and is reminiscent of human disease because microglia accumulate around regions of vascular damage in individuals with $\mathrm{DR},{ }^{25}$ and these vascular lesions are nonuniform in distribution. ${ }^{20}$ In both the prevention and the reversal studies, $\mathrm{F} 4 / 80^{+}$cells in the streptozotocin-control group were approximately threefold to fourfold higher than nondiabetic controls (Figure 5). In addition, in both cohorts, retinas from ACE2-treated diabetic animals revealed decreased $\mathrm{F} 4 / 80^{+}$cells, comparable to nondiabetic control levels. In the prevention cohort, the proportion of these cells that were double-labeled $\mathrm{F} 4 / 80^{+} \mathrm{GFP}^{+}$was approximately $50 \%$, in all groups except streptozotocin-ACE2, which was approximately $25 \%$. This finding represents the proportion of $\mathrm{F} 4 / 80^{+}$cells that are bone marrow derived in contrast to resident. In the reversal cohort, in all groups except streptozotocin-ACE2, nearly all $\mathrm{F} 4 / 80^{+}$cells were also $\mathrm{GFP}^{+}$. In streptozotocin-ACE2, approximately $50 \%$ were double labeled $\mathrm{F} 4 / 80^{+} \mathrm{GFP}^{+}$.

$\mathrm{F} 4 / 80^{+}$cells in the inner plexiform layer and outer plexiform layer of both diabetic and nondiabetic animals, in both the prevention and reversal studies, possessed a regular distribution and high degree of dendritic processes. Thus, the increased numbers of $\mathrm{F} 4 / 80^{+}$cells in the streptozotocincontrol group likely reflects perivascular macrophages at the ganglion cell layer (Figure 5). 

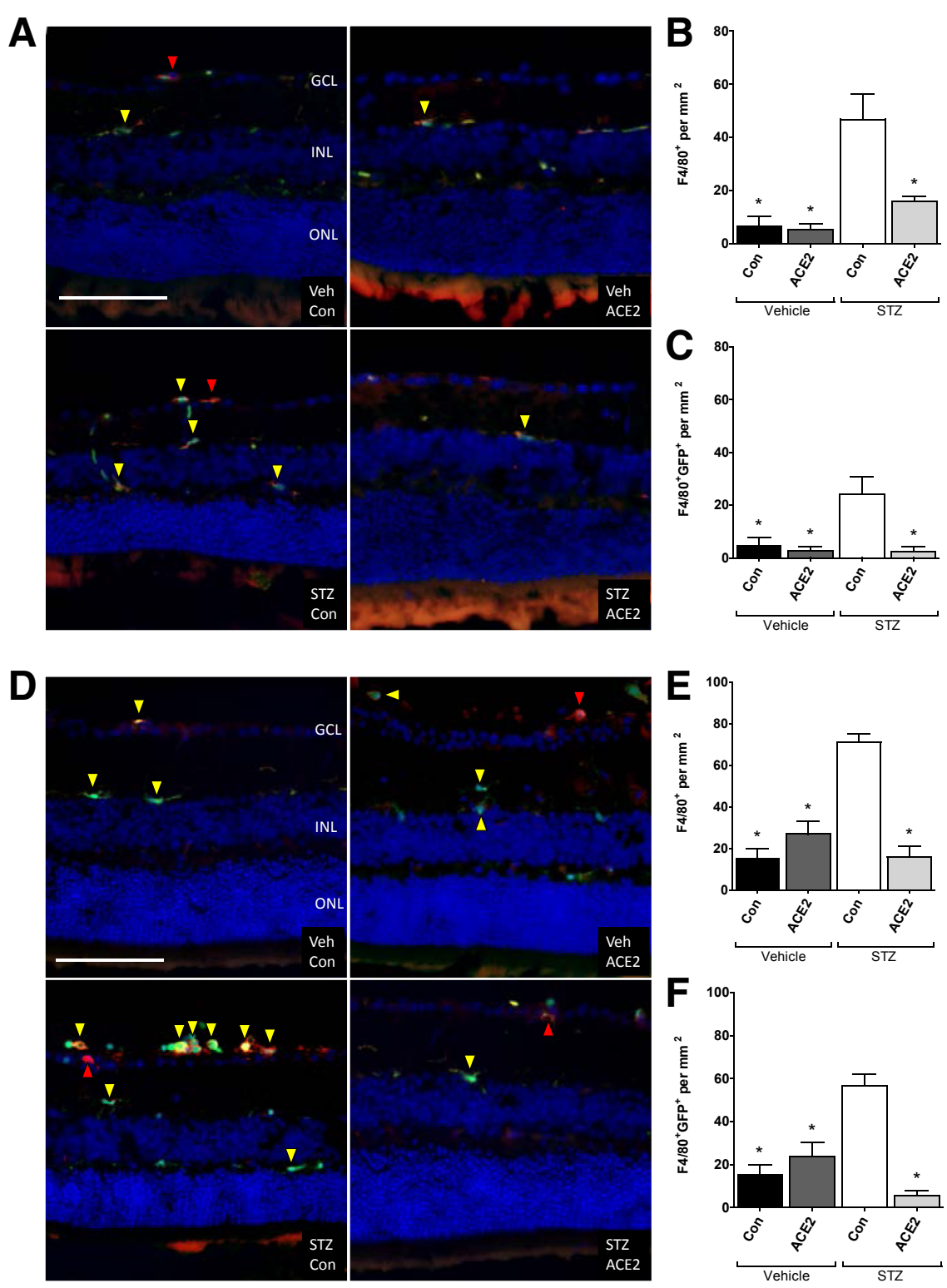

Figure 5 Angiotensin-converting enzyme (ACE)-2 overexpression prevents diabetes-induced increase of macrophage/microglial cells. A: Prevention cohort; representative immunofluorescence images of F4/80-positive (red arrowheads) and F4/80-green fluorescent protein (GFP)-positive (yellow arrowheads) cells in GFP-chimeric, streptozotocin (STZ)-diabetic, and vehicle (Veh)control (Con) mouse retinas. B: Prevention cohort; quantification of $F 4 / 80$-positive cells per square millimeter. C: Prevention cohort; quantification of F4/80-GFP-positive cells per square millimeter. D: Reversal cohort; representative immunofluorescence images of F4/80-positive (red arrowheads) and F4/80-GFP-positive (yellow arrowheads) cells in GFP-chimeric, STZ-diabetic, and Veh-Con mouse retinas. E: Reversal cohort; quantification of $\mathrm{F} 4 / 80$ positive cells per square millimeter. F: Reversal cohort; quantification of F4/80-GFP-positive cells per square millimeter. Data are expressed as means \pm SEM. ${ }^{*} P<0.05$ versus STZ-Con. Scale bar $=100 \mu \mathrm{m} . \mathrm{GCL}$, ganglion cell layer; INL, inner nuclear layer; $\mathrm{ONL}$, outer nuclear layer.

\section{Intracapillary Bone Marrow Cells in Diabetic Mice}

Leukostasis occurs as a result of aberrant leukocyteendothelial cell adhesion and is a major factor in the pathogenesis of DR, contributing to capillary nonperfusion and ischemia. ${ }^{26-28}$ In both the prevention and reversal studies, bone marrow-derived cells were only observed within the vascular lumen in the streptozotocin-control groups (Figure 6) and not in any of the other groups.

\section{Discussion}

There are several key findings from this study. First, local retinal overexpression of ACE2 prevented (Figure 2, A and B) and partially reversed (Figure 2, C and D) the diabetesassociated increase of acellular capillaries. We are not aware of another study that has found a therapy capable of reversing this form of retinal disease, particularly in the presence of persistent untreated hyperglycemia. Second, ACE2 overexpression prevented (Figure 5, A-C) and reversed (Figure 5, D-F) the diabetes-induced increase of macrophages/microglia and prevented the diabetes-associated increase of macroglia immunoreactivity as detected by GFAP (Figure 4, A and B). This finding supports the literature reporting that Ang II mediates increased intercellular adhesion molecule (ICAM)-1 expression, chemokine production, and subsequent macrophage infiltration. ${ }^{29,30}$ Third, local retinal overexpression of ACE2 prevented (Figure 6, A and B) and reversed (Figure 6, C and D) the occurrence of intravascular bone marrow-derived cells, an index of leukostasis. The significance of leukostasis is that it promotes acellular capillary formation and localized ischemia. ${ }^{26-28}$

Our studies suggest that local retinal overexpression of the vasoprotective RAS attenuates the release of 

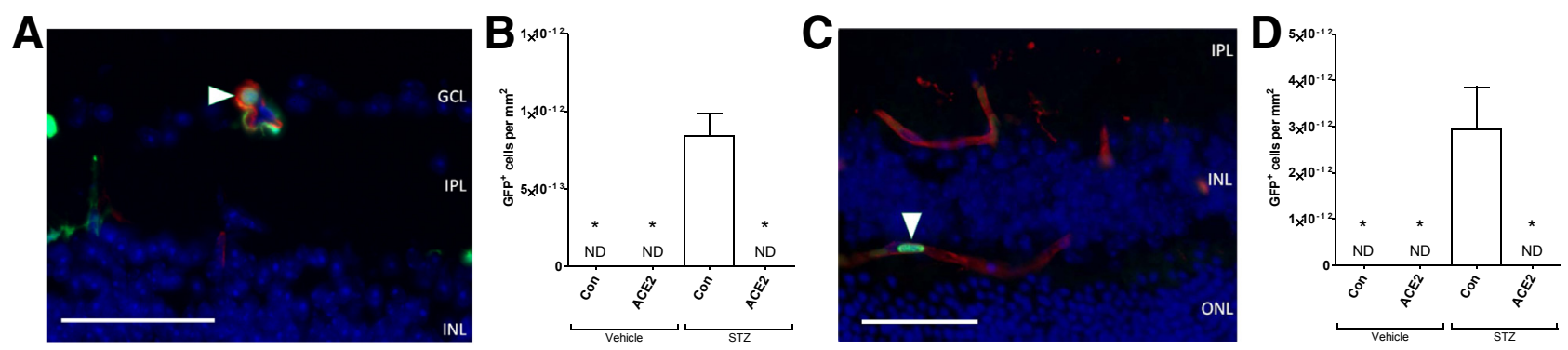

Figure 6 Angiotensin-converting enzyme (ACE)-2 overexpression decreases diabetes-induced increase of intracapillary bone marrow cells. A: Prevention cohort; representative image of a bone marrow-derived cell (arrowhead) located within the lumen of a retinal capillary. B: Prevention cohort; quantification of green fluorescent protein-positive $\left(\mathrm{GFP}^{+}\right)$cells per square millimeter, as observed from retinal cross sections. C: Reversal cohort; representative image of a bone marrow-derived cell (arrowhead) located within the lumen of a retinal capillary. D: Reversal cohort; quantification of GFP ${ }^{+}$cells per square millimeter, as observed from retinal cross sections. Data are expressed as means \pm SEM. ${ }^{\star} P<0.05$ versus streptozotocin (STZ) - control (Con). Scale bar $=50 \mu \mathrm{m}$. $\mathrm{GCL}$, ganglion cell layer; INL, inner nuclear layer; IPL, inner plexiform layer; ND, not detected; ONL, outer nuclear layer.

proinflammatory mediators from the retina because fewer circulating bone marrow-derived inflammatory cells were recruited to the retina and fewer intracapillary bone marrow cells were occluding capillaries. The decline of retinal intracapillary bone marrow cells is the presumed explanation for our finding that ACE2 overexpression prevented and reversed retinal vascular disease, as measured by acellular capillaries. The present study expands on our previous work, ${ }^{10}$ which used two models of DR: an accelerated model in mice (streptozotocin-induced diabetes in eNOS ${ }^{-1-}$ mice) and a long-term model (14 months) in rats (streptozotocin in Sprague-Dawley rats). The primary advancements provided by the present study include the assessment of bone marrow-derived cells in the retina and the partial reversal of DR after a prolonged period of untreated diabetes.

\section{Retinal Overexpression of ACE2 May Attenuate Vasodegeneration by Suppressing Classic RAS Signaling}

The mechanisms that lead to the vasodegenerative phase of DR (eg, pericyte and vascular endothelial cell death) are not entirely known. However, there are multiple RAS-mediated mechanisms that could contribute. Numerous studies have found that AGTR1 activation leads to increased NADPH oxidase activity and increased production of reactive oxygen species, which directly damage the vasculature. In addition, the diabetes-associated increase of leukostasis, which directly contributes to capillary nonperfusion in rodents, ${ }^{26-28}$ is mediated largely by the increase of Ang II and the subsequent increase of NADPH oxidase and $\mathrm{O}_{2}^{-} .{ }^{31}$ For example, in nondiabetic animals, ${ }^{31,32}$ intravitreal administration of Ang II increases leukostasis to comparable levels seen in diabetes. Ang II also sensitizes endothelial cells to tumor necrosis factor (TNF)- $\alpha$-induced ICAM-1 expression and monocyte adhesion, which implies that Ang II is an autocrine regulator of endothelial cell inflammatory responses. ${ }^{33}$ Accordingly, retinal leukostasis and the upregulation of adhesion molecules (eg, ICAM and vascular cell adhesion molecule) are decreased with the blockade of classic RAS. ${ }^{11,34}$ Our studies suggest that local retinal overexpression of ACE2 activity ${ }^{10}$ provides several mechanisms to counter the diabetes-associated increase of classic RAS signaling and the subsequent detrimental effects on the vasculature. ACE2 has a powerful role in opposing the classic RAS in that it converts the proinflammatory/vasoconstrictive Ang II into the anti-inflammatory/vasodilatory Ang(1-7). ${ }^{35,36}$ Thus, ACE2 effectively mitigates the primary vasoconstrictive/ proinflammatory aspects of the classic RAS, while increasing the primary anti-inflammatory/vasodilatory features.

Consistent with the literature, ${ }^{26-28}$ the increase of intracapillary $\mathrm{GFP}^{+}$bone marrow-derived cells in streptozotocincontrol (Figure 6) corresponds with the increase of acellular capillaries (Figure 2). Our finding that bone marrow-derived cells were only observable within the capillary lumen in the streptozotocin-control groups is consistent with the idea that the classic RAS is critically involved in this vascular abnormality. In fact, retinal leukostasis and the up-regulation of adhesion molecules are decreased with classic RAS blockade, ${ }^{11}$ and the absence of intravascular bone marrow cells in the present streptozotocin-ACE2 mice is a tenable mechanistic explanation for the decrease of acellular capillaries. Specifically, in our model, ACE2 metabolism of Ang II would be expected to counter the putative Ang II-mediated increase of chemokine ligand (CCL)-2 and ICAM at the retinal vascular endothelium, ${ }^{29,30}$ thus decreasing recruitment and adhesion of inflammatory cells ${ }^{29}$ to the retinal vasculature (Figure 7). This model is consistent with the notion that, although diabetes induces notable changes in circulating chemokines, as well as their receptor expression on leukocytes, the major diabetes-associated defect originates at the vascular endothelium and is a prerequisite for the development of leukostasis ${ }^{37}$ because decreasing leukocyte adhesion delays development of DR. ${ }^{38}$ The primary limitation of the analysis being performed in cross sections, rather than in retinal flat mounts, is that the vascular density is underrepresented, thus underrepresenting the frequency of events and rendering quantification difficult to compare with published literature (between 0.2 and 4 leukocytes per square millimeter in diabetic retinal flat mounts). ${ }^{31,32}$ 


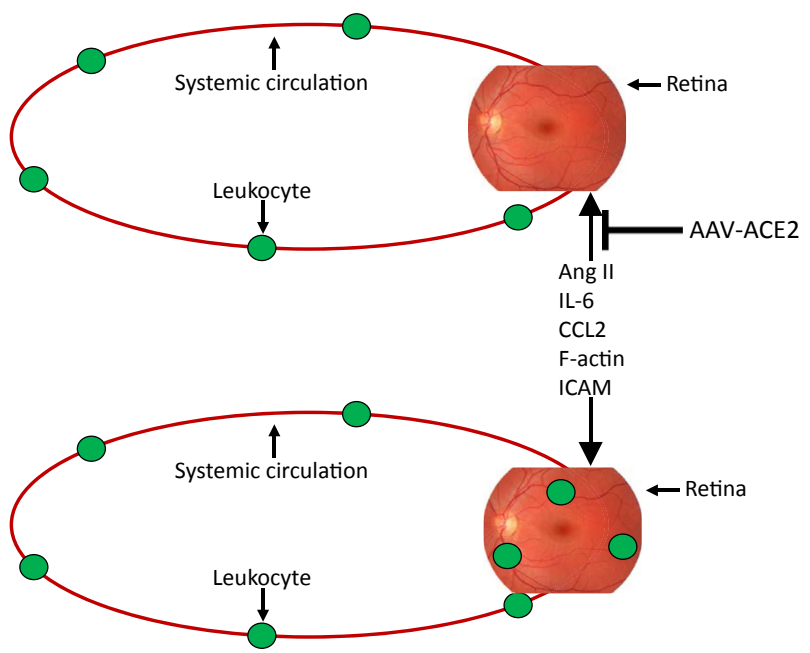

Figure 7 Model for diabetic retinal leukostasis in the present study. In the untreated diabetic eye (bottom image), the relative expression of the vasodeleterious axis exceeds the vasoprotective axis, which up-regulates proinflammatory factors in the retina and adhesion molecules in the retinal circulation. This promotes infiltration and adhesion of leukocytes, which contributes to diabetic retinopathy. Our model proposes that local retinal up-regulation of the vasoprotective axis in diabetic animals (top image), indicated by adenoassociated virus (AAV)-angiotensin-converting enzyme (ACE)-2, will provide protective and reparative mediators on a longterm basis, restoring the balance between the two axes. This will inhibit the up-regulation of proinflammatory factors in the retina and adhesion molecules in the retinal circulation, which prevent infiltration and adhesion of leukocytes, preventing characteristics of diabetic retinopathy, despite systemic hyperglycemia, and an abundance of circulating leukocytes. Ang II, angiotensin II; CCL2, chemokine ligand 2; ICAM, intercellular adhesion molecule.

\section{Retinal Overexpression of ACE2 May Suppress Proinflammatory Signals from Local and Infiltrating Immune Cells}

The structural integrity of the blood-retinal barrier is crucial for retinal homeostasis in part to prevent circulating cytokines from influencing local retinal cell function. Glia and pericytes are important mediators of blood-retinal barrier integrity. Furthermore, the activation and dysfunction of astrocytes (macroglial cells) are key contributors to its breakdown and subsequent increased permeability in DR. ${ }^{39,40}$ Elevated GFAP expression is interpreted as an indication of stress and neurodegeneration or gliosis ${ }^{22}$ and is associated with oxidative stress and increased production of proinflammatory molecules (TNF- $\alpha$, IL- $1 \beta$, and inducible nitric oxide synthase) in retinal astrocytes. ${ }^{21}$ Our findings are consistent with the literature on diabetic mouse models in that untreated diabetes was associated with elevated retinal GFAP immunoreactivity compared with nondiabetic controls in the prevention cohort (Figure 4, A and B). Retinal overexpression of ACE2 in diabetic animals prevented this increase, presumably functioning to improve blood-retinal barrier function. The most likely explanation for this beneficial effect of ACE2 overexpression is the collective effect at AGTR1 on astrocytes ${ }^{41}$ and other immune cells of the retina. For example, decreased signaling through AGTR1 decreases $\mathrm{GFAP}^{+}$astrocytes, ${ }^{42}$ which can be accomplished by increased metabolism of Ang II and generation of $\operatorname{Ang}(1-7){ }^{43}$ Furthermore, there is increasing evidence to suggest that glial cells act as an intermediary between oxidative stress and neuroinflammation. ${ }^{44}$ Oxidative damage to glial cells produces excessive proinflammatory cytokines, which activates neuronal membrane receptors to induce inflammatory pathways, resulting in neuroinflammation. ${ }^{45}$ Thus, by preventing gliosis, overexpression of ACE2 would be expected to mitigate the diabetes-associated increase of proinflammatory molecules, as well as the disruption of the blood-retinal barrier. This effect may be particularly important to suppress microglial hyperactivation and the putative feed-forward increase of inflammation and oxidative stress.

In the reversal study, GFAP immunoreactivity in the untreated diabetic animals was not different from the other groups (Figure 4, C and D). Moreover, GFAP immunofluorescence was higher in the reversal study by approximately threefold compared with the prevention cohort. A possible explanation for this is that GFAP expression increases with aging in $\mathrm{C} 57$ mice $^{23}$; animals in the reversal study were approximately $50 \%$ older than animals in the prevention study. However, there appears to be a species difference (mice versus primates and rats) regarding GFAP immunoreactivity in Müller cells during diabetes, which is consistent with our present findings. GFAP immunoreactivity in Müller cells increases in both primates and rats after a relatively short duration of diabetes. Asnaghi et $\mathrm{al}^{46}$ assessed GFAP immunoreactivity in rats but also in mice. Diabetic rats had increased Müller cell immunoreactivity for GFAP. However, at 10 or 24 weeks of diabetes, GFAP staining in diabetic mice was typical of astrocytes and appeared unaltered, and there was no indication of Müller cell reactivity. Barber et $\mathrm{al}^{47}$ found that Ins2 Atika mice had microglial activation but no increase in GFAP expression by Müller cells. Similarly, in mice with alloxan-induced diabetes, no glial reaction, as assessed by GFAP labeling, could be detected 1 or 3 months after induction. ${ }^{48}$ Finally, FeitLeichman et $\mathrm{al}^{49}$ revealed a transient increase in GFAP ( 1 to 2 months) in astrocytes in the ganglion cell layer but not in Müller cells of streptozotocin-diabetic mice. In complete agreement with our findings, this elevation of GFAP returned toward normal with longer durations of diabetes (12 months). Feit-Leichman et $\mathrm{al}^{49}$ concluded that although diabetes transiently activated apoptotic signaling in a small population of neurons in the mouse retina, the damage was probably not great enough to induce Müller gliosis in mice.

The classic RAS is indirectly involved in the pathogenesis of vascular diseases by many different mechanisms, including modulation of immune cell function and/or recruitment. Ang II activation of the p38-mitogen-activated protein kinase-dependent pathway promotes the production of CCL2, a soluble chemotactic cytokine, in blood vessels. ${ }^{30}$ Importantly, CCL2 is the most common chemokine found to be elevated in serum and vitreous of patients with 
DR. ${ }^{50,51}$ The study by Hazra et $\mathrm{al}^{5}$ found that monocytes expressing the CCL2 receptor (CCR2) are present in increased numbers in the circulation and are found to accumulate in the retina of streptozotocin-diabetic mice, implicating the CCL2-CCR2 axis in the development of DR.

There are two distinct populations of monocyte-derived cells in the mammalian retina. Perivascular macrophages are situated among the inner retinal vasculature in the ganglion cell layer, and the retinal microglia are located within the inner plexiform layer and outer plexiform layer. ${ }^{52}$ Basal levels of microglial activity are essential for maintaining retinal homeostasis, including normal vascularization of the retina. ${ }^{53}$ However, their hyperactivation is implicated in the progression of many diseases, including DR. ${ }^{54}$ Hyperactivation is characterized by the release of toxic molecules (TNF- $\alpha, \mathrm{IL}-1 \beta, \mathrm{O}_{2}^{-}$, and nitric oxide) that are intended to destroy offending pathogens. ${ }^{54,55}$ In fact, microglia are considered the early primary source of IL-1 in central nervous system injury, infection, and inflammation. IL-1 $\beta$ is a trigger of the neuroinflammatory cascade, ${ }^{56}$ which (along with TNF- $\alpha$ ) increases caspase 3 activity, inducing endothelial cell apoptosis, ${ }^{57,58}$ which could directly contribute to the increase of acellular capillaries in DR (Figure 2). Activated microglia have also been proposed to stimulate a cycle of inflammation that recruits leukocytes, causes vascular damage, and directly induces glial dysfunction and neuronal cell death through the release of cytotoxic substances. ${ }^{59}$ Thus, early destruction of the blood-retinal barrier in $\mathrm{DR}^{60}$ may be driven by glial hyperactivation. ${ }^{59}$ Exposure of microglia to inflammatory agents (including advanced glycation end products, TNF- $\alpha$, IL-1, IL- 6 , interferon- $\gamma$ ) results in microglial activation and production of inflammatory mediators (eg, TNF- $\alpha$, IL-1, IL-6, IL-8, CCL2), ${ }^{61-63}$ functioning in a paracrine and/or autocrine feed-forward loop to further compromise the blood-retinal barrier and elevate local retinal inflammation. ${ }^{54,61,64}$ Therefore, we propose that the decline of microglial/macrophage cells in streptozotocinACE2 is at least partly responsible for the prevention and partial reversal of retinal vascular disease in the present study (Figure 2).

In both the prevention and reversal studies, $\mathrm{F} 4 / 80^{+}$ macrophage/microglial cells located within the ganglion cell layer of diabetic and nondiabetic animals were predominantly ameboid or elongated in appearance, consistent with an activated phenotype. These cells were increased in streptozotocin-control by approximately threefold to fourfold compared with nondiabetic or ACE2-treated diabetic, consistent with previous findings. ${ }^{65,66}$ Also consistent with our findings (Figure 5), DR has generally been found to be associated with increased microglia number near retinal vasculature in the inner retinal layers and in the outer plexiform layer, ${ }^{25,67}$ normally localizing anterior to the outer nuclear layer. ${ }^{52}$ This organization within the ganglion cell layer is consistent with the finding, in individuals with $\mathrm{DR}$, that microglia accumulate around regions of vascular damage $^{25}$ and that vascular lesions in the diabetic retina are nonuniform in distribution. ${ }^{20}$ However, microglia have also been observed in the outer nuclear and photoreceptor layers after 14 to 16 months of streptozotocin-induced diabetes, presumably migrating to areas of neuronal damage. ${ }^{67} \mathrm{An}$ alternative possibility is that these cells are responsible for the nonuniform pattern of vascular lesions that characterize the diabetic retina. ${ }^{20}$ It is not possible to determine, in this study, whether localized areas of macrophage hyperactivation contribute to neurovascular damage or whether macrophages migrate preferentially to areas of neurovascular damage. However, the literature supports the concept that macrophages and inflammatory cells play a major role in the development of vascular alterations in diabetes. ${ }^{68,69}$

One possible mechanism whereby ACE2 overexpression attenuates the diabetes-associated increase of macrophage/ microglial cells (Figure 5) is attributable to the ability of Ang(1-7) to antagonize AGTR1s (which are expressed on microglia). AGTR1 blockade with valsartan effectively decreased microglial density in a rodent model of DR. ${ }^{70}$ Consistent with our findings, McVicar et $\mathrm{al}^{65}$ found a significant increase of $\mathrm{F} 4 / 80^{+}$microglia in the retina when compared with nondiabetic controls, after 3 and 6 months of diabetes in mice. Similarly, Muther et $\mathrm{al}^{71}$ observed a regular distribution of $\mathrm{F} 4 / 80^{+}$in the healthy mouse retina.

\section{Topics for Future Investigation}

There are several interesting observations from this study that remain only partially explained. Despite the improvement of retinal vasculature in the diabetic AAVACE2 animals, we still observed bone marrow-derived, perivascular cells, which possessed dendritic processes and were labeled with F4/80. The question remains whether up-regulation of the retinal vasoprotective RAS induces a phenotypic shift in the macrophage/microglial cells toward more anti-inflammatory cells. Another interesting observation was that infiltrating bone marrow cells localized to the diabetic retina in clusters, which begs the question whether they are localizing to vascular/neural injury or causing it. An important next step is to confirm these findings in a type 2 diabetes model because the prevalence of type 2 is much greater than type 1 and accounts for most DR cases. However, the type 1 studies performed are justifiable because the incidence of type 1 diabetes is also increasing and the risk of DR in individuals with type 1 diabetes is greater than in those with type 2 diabetes. $^{72}$

Because the diabetic retina is strongly associated with proinflammatory molecules, future studies should consider the addition of an antioxidant to gene therapy to enhance outcomes. For example, in the reversal study, the numbers of acellular capillaries were only partially reversed, and the increase in GFAP expression was not reversed by vasoprotective RAS overexpression. It is possible that a substantial proinflammatory stimulus remains, despite the overexpression of protective mediators. 


\section{Conclusions}

The findings of this study support the overall hypothesis that by opposing the disproportionate increase of the local retinal vasodeleterious RAS, key indices of DR can be prevented and reversed in rodents with type 1 diabetes. Specifically, AAV-mediated overexpression of retinal ACE2 decreased the diabetes-associated increase of intracapillary bone marrow cells, which we believe is at least partly responsible for the improvement of retinal vascular disease in diabetic animals. The use of $\mathrm{GFP}^{+}$-chimeric mice allowed us to distinguish infiltrating cells from resident cells and in conjunction with immunohistochemistry allowed us to confirm a deleterious contribution of the cells from the diabetic bone marrow. Accordingly, we observed an attenuation of glial/macrophage immunoreactivity in the diabetic retina with our gene therapy approach, supporting the contention that the overall inflammatory status of the retina was improved. Thus, we propose that local retinal overexpression of vasoprotective RAS successfully counters the diabetes-associated elevation of vasodeleterious RAS, which not only prevented but also reversed several characteristics of long-standing DR, despite systemic hyperglycemia. These findings are very exciting because it has traditionally been believed that acellular capillaries represent irreversible lesions. Collectively, the results of this set of studies provide further support for the hypothesis that an imbalance between the two axes of the RAS is a key initial event that leads to development of diabetic microvascular complications. The use of AAV-ACE2 via intravitreal injection may represent a novel strategy for DR in humans and should be considered as a possible therapeutic approach for other microvascular and macrovascular complications of diabetes.

\section{Acknowledgments}

We thank Neal Benson from the cytometry core at the Interdisciplinary Center for Biotechnology Research at the University of Florida.

M.B.G. is the guarantor of this work and, as such, had full access to all data and takes responsibility for the integrity of the data and the accuracy of the data analysis.

\section{Supplemental Data}

Supplemental material for this article can be found at http://dx.doi.org/10.1016/j.ajpath.2016.01.023.

\section{References}

1. Busik JV, Tikhonenko M, Bhatwadekar A, Opreanu M, Yakubova N, Caballero S, Player D, Nakagawa T, Afzal A, Kielczewski J, Sochacki A, Hasty S, Li Calzi S, Kim S, Duclas SK, Segal MS, Guberski DL, Esselman WJ, Boulton ME, Grant MB: Diabetic retinopathy is associated with bone marrow neuropathy and a depressed peripheral clock. J Exp Med 2009, 206:2897-2906

2. Dominguez JM 2nd, Yorek MA, Grant MB: Combination therapies prevent the neuropathic, proinflammatory characteristics of bone marrow in streptozotocin-induced diabetic rats. Diabetes 2015, 64 643-653

3. Loomans CJ, van Haperen R, Duijs JM, Verseyden C, de Crom R, Leenen PJ, Drexhage HA, de Boer HC, de Koning EJ, Rabelink TJ, Staal FJ, van Zonneveld AJ: Differentiation of bone marrow-derived endothelial progenitor cells is shifted into a proinflammatory phenotype by hyperglycemia. Mol Med 2009, 15:152-159

4. Fadini GP, de Kreutzenberg SV, Boscaro E, Albiero M, Cappellari R, Krankel N, Landmesser U, Toniolo A, Bolego C, Cignarella A, Seeger F, Dimmeler S, Zeiher A, Agostini C, Avogaro A: An unbalanced monocyte polarisation in peripheral blood and bone marrow of patients with type 2 diabetes has an impact on microangiopathy. Diabetologia 2013, 56:1856-1866

5. Hazra S, Jarajapu YP, Stepps V, Caballero S, Thinschmidt JS Sautina L, Bengtsson N, Licalzi S, Dominguez J, Kern TS, Segal MS, Ash JD, Saban DR, Bartelmez SH, Grant MB: Long-term type 1 diabetes influences haematopoietic stem cells by reducing vascular repair potential and increasing inflammatory monocyte generation in a murine model. Diabetologia 2013, 56:644-653

6. UK Prospective Diabetes Study (UKPDS) Group: Intensive bloodglucose control with sulphonylureas or insulin compared with conventional treatment and risk of complications in patients with type 2 diabetes (UKPDS 33). Lancet 1998, 352:837-853

7. Danser AH, Derkx FH, Admiraal PJ, Deinum J, de Jong PT, Schalekamp MA: Angiotensin levels in the eye. Invest Ophthalmol Vis Sci 1994, 35:1008-1018

8. Danser AH, van den Dorpel MA, Deinum J, Derkx FH, Franken AA, Peperkamp E, de Jong PT, Schalekamp MA: Renin, prorenin, and immunoreactive renin in vitreous fluid from eyes with and without diabetic retinopathy. J Clin Endocrinol Metab 1989, 68:160-167

9. Kim JH, Kim JH, Yu YS, Cho CS, Kim KW: Blockade of angiotensin II attenuates VEGF-mediated blood-retinal barrier breakdown in diabetic retinopathy. J Cereb Blood Flow Metab 2009, 29: 621-628

10. Verma A, Shan Z, Lei B, Yuan L, Liu X, Nakagawa T, Grant MB, Lewin AS, Hauswirth WW, Raizada MK, Li Q: ACE2 and Ang-(1-7) confer protection against development of diabetic retinopathy. Mol Ther 2012, 20:28-36

11. Zhang JZ, Xi X, Gao L, Kern TS: Captopril inhibits capillary degeneration in the early stages of diabetic retinopathy. Curr Eye Res 2007, 32:883-889

12. Sjolie AK, Klein R, Porta M, Orchard T, Fuller J, Parving HH, Bilous R, Chaturvedi N; DIRECT Programme Study Group: Effect of candesartan on progression and regression of retinopathy in type 2 diabetes (DIRECT-Protect 2): a randomised placebo-controlled trial. Lancet 2008, 372:1385-1393

13. Chaturvedi N, Porta M, Klein R, Orchard T, Fuller J, Parving HH, Bilous R, Sjolie AK; DIRECT Programme Study Group: Effect of candesartan on prevention (DIRECT-Prevent 1) and progression (DIRECT-Protect 1) of retinopathy in type 1 diabetes: randomised, placebo-controlled trials. Lancet 2008, 372:1394-1402

14. Patel VB, Bodiga S, Basu R, Das SK, Wang W, Wang Z, Lo J, Grant MB, Zhong J, Kassiri Z, Oudit GY: Loss of angiotensinconverting enzyme-2 exacerbates diabetic cardiovascular complications and leads to systolic and vascular dysfunction: a critical role of the angiotensin II/AT1 receptor axis. Circ Res 2012, 110: $1322-1335$

15. Tipnis SR, Hooper NM, Hyde R, Karran E, Christie G, Turner AJ: A human homolog of angiotensin-converting enzyme. Cloning and functional expression as a captopril-insensitive carboxypeptidase. J Biol Chem 2000, 275:33238-33243

16. Grant MB, May WS, Caballero S, Brown GA, Guthrie SM, Mames RN, Byrne BJ, Vaught T, Spoerri PE, Peck AB, Scott EW 
Adult hematopoietic stem cells provide functional hemangioblast activity during retinal neovascularization. Nat Med 2002, 8:607-612

17. Huentelman MJ, Zubcevic J, Katovich MJ, Raizada MK: Cloning and characterization of a secreted form of angiotensin-converting enzyme 2. Regul Pept 2004, 122:61-67

18. Kuwabara T, Cogan DG: Studies of retinal vascular patterns, I: normal architecture. Arch Ophthalmol 1960, 64:904-911

19. Hu P, Thinschmidt JS, Yan Y, Hazra S, Bhatwadekar A, Caballero S, Salazar T, Miyan JA, Li W, Derbenev A, Zsombok A, Tikhonenko M, Dominguez JM 2nd, McGorray SP, Saban DR, Boulton ME, Busik JV, Raizada MK, Chan-Ling T, Grant MB: CNS inflammation and bone marrow neuropathy in type 1 diabetes. Am J Pathol 2013, 183:1608-1620

20. Kern TS, Engerman RL: Vascular lesions in diabetes are distributed non-uniformly within the retina. Exp Eye Res 1995, 60:545-549

21. Shin ES, Huang Q, Gurel Z, Sorenson CM, Sheibani N: High glucose alters retinal astrocytes phenotype through increased production of inflammatory cytokines and oxidative stress. PLoS One 2014, 9: e103148

22. Middeldorp J, Hol EM: GFAP in health and disease. Prog Neurobiol 2011, 93:421-443

23. Formichella CR, Abella SK, Sims SM, Cathcart HM, Sappington RM: Astrocyte reactivity: a biomarker for retinal ganglion cell health in retinal neurodegeneration. J Clin Cell Immunol 2014, 5

24. Austyn JM, Gordon S: F4/80, a monoclonal antibody directed specifically against the mouse macrophage. Eur J Immunol 1981, 11: 805-815

25. Zeng HY, Green WR, Tso MO: Microglial activation in human diabetic retinopathy. Arch Ophthalmol 2008, 126:227-232

26. Chibber R, Ben-Mahmud BM, Chibber S, Kohner EM: Leukocytes in diabetic retinopathy. Curr Diabetes Rev 2007, 3:3-14

27. Kern TS: Contributions of inflammatory processes to the development of the early stages of diabetic retinopathy. Exp Diabetes Res 2007, 2007:95103

28. Adamis AP, Berman AJ: Immunological mechanisms in the pathogenesis of diabetic retinopathy. Semin Immunopathol 2008, 30: $65-84$

29. Liu J, Yang F, Yang XP, Jankowski M, Pagano PJ: NAD(P)H oxidase mediates angiotensin II-induced vascular macrophage infiltration and medial hypertrophy. Arterioscler Thromb Vasc Biol 2003, 23: 776-782

30. Takahashi M, Suzuki E, Takeda R, Oba S, Nishimatsu H, Kimura K, Nagano T, Nagai R, Hirata Y: Angiotensin II and tumor necrosis factor-alpha synergistically promote monocyte chemoattractant protein-1 expression: roles of NF-kappaB, p38, and reactive oxygen species. Am J Physiol Heart Circ Physiol 2008, 294:H2879-H2888

31. Chen P, Guo AM, Edwards PA, Trick G, Scicli AG: Role of NADPH oxidase and ANG II in diabetes-induced retinal leukostasis. Am J Physiol Regul Integr Comp Physiol 2007, 293:R1619-R1629

32. Rojas M, Zhang W, Lee DL, Romero MJ, Nguyen DT, Al-Shabrawey M, Tsai NT, Liou GI, Brands MW, Caldwell RW, Caldwell RB: Role of IL-6 in angiotensin II-induced retinal vascular inflammation. Invest Ophthalmol Vis Sci 2010, 51:1709-1718

33. Fiedler U, Reiss Y, Scharpfenecker M, Grunow V, Koidl S, Thurston G, Gale NW, Witzenrath M, Rosseau S, Suttorp N, Sobke A, Herrmann M, Preissner KT, Vajkoczy P, Augustin HG: Angiopoietin-2 sensitizes endothelial cells to TNF-alpha and has a crucial role in the induction of inflammation. Nat Med 2006, 12: 235-239

34. Chen P, Scicli GM, Guo M, Fenstermacher JD, Dahl D, Edwards PA, Scicli AG: Role of angiotensin II in retinal leukostasis in the diabetic rat. Exp Eye Res 2006, 83:1041-1051

35. Vickers C, Hales P, Kaushik V, Dick L, Gavin J, Tang J, Godbout K, Parsons T, Baronas E, Hsieh F, Acton S, Patane M, Nichols A, Tummino P: Hydrolysis of biological peptides by human angiotensinconverting enzyme-related carboxypeptidase. J Biol Chem 2002, 277: $14838-14843$
36. Donoghue M, Hsieh F, Baronas E, Godbout K, Gosselin M, Stagliano N, Donovan M, Woolf B, Robison K, Jeyaseelan R, Breitbart RE, Acton S: A novel angiotensin-converting enzymerelated carboxypeptidase (ACE2) converts angiotensin I to angiotensin 1-9. Circ Res 2000, 87:E1-E9

37. Serra AM, Waddell J, Manivannan A, Xu H, Cotter M, Forrester JV: $\mathrm{CD} 11 \mathrm{~b}+$ bone marrow-derived monocytes are the major leukocyte subset responsible for retinal capillary leukostasis in experimental diabetes in mouse and express high levels of CCR5 in the circulation. Am J Pathol 2012, 181:719-727

38. Joussen AM, Poulaki V, Le ML, Koizumi K, Esser C, Janicki H, Schraermeyer U, Kociok N, Fauser S, Kirchhof B, Kern TS, Adamis AP: A central role for inflammation in the pathogenesis of diabetic retinopathy. FASEB J 2004, 18:1450-1452

39. Shen W, Li S, Chung SH, Gillies MC: Retinal vascular changes after glial disruption in rats. J Neurosci Res 2010, 88:1485-1499

40. Zheng X, Li PH, Song SF: Expression of glial fibrillary acidic protein in retina of rats in acute experimental autoimmune encephalomyelitis [in Chinese]. Sichuan Da Xue Xue Bao Yi Xue Ban 2008, 39: 719-722

41. Fogarty DJ, Sanchez-Gomez MV, Matute C: Multiple angiotensin receptor subtypes in normal and tumor astrocytes in vitro. Glia 2002, 39:304-313

42. Kono S, Kurata T, Sato K, Omote Y, Hishikawa N, Yamashita T, Deguchi K, Abe K: Neurovascular protection by telmisartan via reducing neuroinflammation in stroke-resistant spontaneously hypertensive rat brain after ischemic stroke. J Stroke Cerebrovasc Dis 2015, 24:537-547

43. Gironacci MM, Coba MP, Pena C: Angiotensin-(1-7) binds at the type 1 angiotensin II receptors in rat renal cortex. Regul Pept 1999 84:51-54

44. Scholz J, Woolf CJ: The neuropathic pain triad: neurons, immune cells and glia. Nat Neurosci 2007, 10:1361-1368

45. Myers RR, Campana WM, Shubayev VI: The role of neuroinflammation in neuropathic pain: mechanisms and therapeutic targets. Drug Discov Today 2006, 11:8-20

46. Asnaghi V, Gerhardinger C, Hoehn T, Adeboje A, Lorenzi M: A role for the polyol pathway in the early neuroretinal apoptosis and glial changes induced by diabetes in the rat. Diabetes 2003, 52:506-511

47. Barber AJ, Antonetti DA, Kern TS, Reiter CE, Soans RS, Krady JK, Levison SW, Gardner TW, Bronson SK: The Ins2Akita mouse as a model of early retinal complications in diabetes. Invest Ophthalmol Vis Sci 2005, 46:2210-2218

48. Gaucher D, Chiappore JA, Paques M, Simonutti M, Boitard C, Sahel JA, Massin P, Picaud S: Microglial changes occur without neural cell death in diabetic retinopathy. Vision Res 2007, 47: 612-623

49. Feit-Leichman RA, Kinouchi R, Takeda M, Fan Z, Mohr S, Kern TS, Chen DF: Vascular damage in a mouse model of diabetic retinopathy: relation to neuronal and glial changes. Invest Ophthalmol Vis Sci 2005, 46:4281-4287

50. Abu el-Asrar AM, Van Damme J, Put W, Veckeneer M, Dralands L, Billiau A, Missotten L: Monocyte chemotactic protein-1 in proliferative vitreoretinal disorders. Am J Ophthalmol 1997, 123: 599-606

51. Elner SG, Elner VM, Jaffe GJ, Stuart A, Kunkel SL, Strieter RM: Cytokines in proliferative diabetic retinopathy and proliferative vitreoretinopathy. Curr Eye Res 1995, 14:1045-1053

52. Chen L, Yang P, Kijlstra A: Distribution, markers, and functions of retinal microglia. Ocul Immunol Inflamm 2002, 10:27-39

53. Checchin D, Sennlaub F, Levavasseur E, Leduc M, Chemtob S: Potential role of microglia in retinal blood vessel formation. Invest Ophthalmol Vis Sci 2006, 47:3595-3602

54. Krady JK, Basu A, Allen CM, Xu Y, LaNoue KF, Gardner TW, Levison SW: Minocycline reduces proinflammatory cytokine expression, microglial activation, and caspase- 3 activation in a rodent model of diabetic retinopathy. Diabetes 2005, 54:1559-1565 
55. Neumann H, Kotter MR, Franklin RJ: Debris clearance by microglia: an essential link between degeneration and regeneration. Brain 2009, 132:288-295

56. Liu Y, Biarnes Costa M, Gerhardinger C: IL-1beta is upregulated in the diabetic retina and retinal vessels: cell-specific effect of high glucose and IL-1beta autostimulation. PLoS One 2012, 7:e36949

57. Aveleira CA, Lin CM, Abcouwer SF, Ambrosio AF, Antonetti DA: TNF-alpha signals through PKCzeta/NF-kappaB to alter the tight junction complex and increase retinal endothelial cell permeability. Diabetes 2010, 59:2872-2882

58. Kowluru RA, Odenbach S: Role of interleukin-1beta in the pathogenesis of diabetic retinopathy. $\mathrm{Br} \mathrm{J}$ Ophthalmol 2004, 88: $1343-1347$

59. Yang LP, Sun HL, Wu LM, Guo XJ, Dou HL, Tso MO, Zhao L, Li SM: Baicalein reduces inflammatory process in a rodent model of diabetic retinopathy. Invest Ophthalmol Vis Sci 2009, 50: $2319-2327$

60. Xu Q, Qaum T, Adamis AP: Sensitive blood-retinal barrier breakdown quantitation using Evans blue. Invest Ophthalmol Vis Sci 2001, 42:789-794

61. Wang AL, Yu AC, He QH, Zhu X, Tso MO: AGEs mediated expression and secretion of TNF alpha in rat retinal microglia. Exp Eye Res 2007, 84:905-913

62. Kaul K, Hodgkinson A, Tarr JM, Kohner EM, Chibber R: Is inflammation a common retinal-renal-nerve pathogenic link in diabetes? Curr Diabetes Rev 2010, 6:294-303

63. Panenka W, Jijon H, Herx LM, Armstrong JN, Feighan D, Wei T, Yong VW, Ransohoff RM, MacVicar BA: P2X7-like receptor activation in astrocytes increases chemokine monocyte chemoattractant protein-1 expression via mitogen-activated protein kinase. J Neurosci 2001, 21:7135-7142

64. Wang AL, Yu AC, Lau LT, Lee C, Wu le M, Zhu X, Tso MO: Minocycline inhibits LPS-induced retinal microglia activation. Neurochem Int 2005, 47:152-158
65. McVicar CM, Ward M, Colhoun LM, Guduric-Fuchs J, Bierhaus A, Fleming T, Schlotterer A, Kolibabka M, Hammes HP, Chen M, Stitt AW: Role of the receptor for advanced glycation endproducts (RAGE) in retinal vasodegenerative pathology during diabetes in mice. Diabetologia 2015, 58:1129-1137

66. Rangasamy S, McGuire PG, Franco Nitta C, Monickaraj F, Oruganti SR, Das A: Chemokine mediated monocyte trafficking into the retina: role of inflammation in alteration of the blood-retinal barrier in diabetic retinopathy. PLoS One 2014, 9:e108508

67. Zeng XX, Ng YK, Ling EA: Neuronal and microglial response in the retina of streptozotocin-induced diabetic rats. Vis Neurosci 2000, 17: 463-471

68. Joussen AM, Poulaki V, Mitsiades N, Cai WY, Suzuma I, Pak J, Ju ST, Rook SL, Esser P, Mitsiades CS, Kirchhof B, Adamis AP Aiello LP: Suppression of Fas-FasL-induced endothelial cell apoptosis prevents diabetic blood-retinal barrier breakdown in a model of streptozotocin-induced diabetes. FASEB J 2003, 17:76-78

69. Joussen AM, Murata T, Tsujikawa A, Kirchhof B, Bursell SE, Adamis AP: Leukocyte-mediated endothelial cell injury and death in the diabetic retina. Am J Pathol 2001, 158:147-152

70. Deliyanti D, Miller AG, Tan G, Binger KJ, Samson AL, WilkinsonBerka JL: Neovascularization is attenuated with aldosterone synthase inhibition in rats with retinopathy. Hypertension 2012, 59:607-613

71. Muther PS, Semkova I, Schmidt K, Abari E, Kuebbeler M, Beyer M Abken H, Meyer KL, Kociok N, Joussen AM: Conditions of retinal glial and inflammatory cell activation after irradiation in a GFPchimeric mouse model. Invest Ophthalmol Vis Sci 2010, 51: 4831-4839

72. ACCORD Study Group, Chew EY, Ambrosius WT, Davis MD, Danis RP, Gangaputra S, Greven CM, Hubbard L, Esser BA, Lovato JF, Perdue LH, Goff DC Jr, Cushman WC, Ginsberg HN, Elam MB, Genuth S, Gerstein HC, Schubart U, Fine LJ: Effects of medical therapies on retinopathy progression in type 2 diabetes. N Engl J Med 2010, 363:233-244 